D.O.I:10.3895/S1808-04482012000400001

\title{
THE INCOME FROM THE GARBAGE: A CASE STUDY ON THE COLLECTION AND SELECTION OF RECYCLABLE SOLID WASTE
}

\section{A RECEITA QUE VEM DO LIXO: ESTUDO DE CASO SOBRE A COLETA, SELEÇÃO E RECICLAGEM DE LIXO DOMÉSTICO}

\author{
Ubiratã Tortato $^{1}$; Marco Antonio Murara ${ }^{2}$ \\ ${ }^{1}$ Pontifícia Universidade Católica do Paraná - PUCPR - Curitiba - Brasil. \\ ubirata.tortato@pucpr.br \\ ${ }^{2}$ Pontifícia Universidade Católica do Paraná - PUCPR - Curitiba - Brasil. \\ marcoantonio@murara.com.br
}

\begin{abstract}
This article describes the planning process, collection, distribution, selection, and compression into bales of household solid waste of the city of Jaraguá do Sul in southern Brazil. Background information was obtained in the company responsible to perform the selective collection, in the Cooperative and Association of Collectors, and the company that sells the separated and compressed / crushed material to the industry. A survey was carried out in the programs created by public agencies to raise awareness among the population about the importance of the selection of household waste. Qualitative data were collected through semi-structured and non-participant observation. From the analysis of results it can be concluded that the lack of training of association members and cooperated personnel, due to their low educational level, may explain the absence of planning. It is also possible to affirm that the municipal government has developed programs to raise the awareness of the population, but there is still a little response by the people living that county.
\end{abstract}

Key-words: Reverse Logistics, Waste Recycling, Income Generation.

\section{Introduction}

Changes in social structure and the characteristics of families, which are becoming smaller, besides the large number of people living alone, have increased the release of products with a shorter life cycle and different sizes of containers. If on one hand this makes the consumer's life more practical and maximizes industrial results, on the other hand it increases the environmental burden to the society as a whole. According to Forlin and Faria (2002), the ones who will pay the price for this predatory habit of consumption are the natural environment and future generations. The characteristics of this situation provide a setting for an increasingly heated debate: the collection, disposal and reuse of household solid waste. Somehow the production of solid waste, collected in a selective manner, allows for the generation of employment, income and new products with increasing intensity. 
In general, people with little schooling and few employment prospects tend to fit the profile of those who work with the collection, selection and compacting of post-consumption solid waste. The government and private companies all over the country have broadly encouraged environmentally and socially correct actions; however, there are concerns about working conditions and the form of organization of the entities that process this material, generally associations and cooperatives of recyclable material collectors. The research was conducted in the city of Jaraguá do Sul, State of Santa Catarina, southern Brazil, which has 143,206 inhabitants and 45,032 households. Jaraguá do Sul is the ninth most populous city and fifth economy in the state (IBGE, 2010). According to the Atlas of Human Development of 2000, produced by the United Nations Development Programme (UNDP), the city is in 9th place in Santa Catarina and 32nd in the country, with a HDI-M of 0.85 on an index that varies between 0 and 1 . The general objective of the article is to identify how the process of collection, selection and compaction of solid waste in Jaraguá do Sul is undertaken, what is the profile of the workers involved, and how the management of the entities that execute this work is organized.

The importance of this article lies in the possibility of elucidating the reality of the actors who are inserted in recyclable solid waste as well as the public policy for the sector, contributing to previous studies. Furthermore, the data can indicate to society the need of improving the treatment of recyclable solid waste, which may have a positive impact on the workers' income and work conditions.

\section{Literature review}

\subsection{Reverse logistics}

Leite (2003) conceptualizes reverse logistics (RL) as the area of business logistics that plans, operates and controls the flow and corresponding information logistics of the return of post-sale and post-consumer goods to the business cycle or production cycle, through the channels of reverse distribution, adding diverse types of value. This distinction is necessary, although there are innumerable interdependencies that will be examined as follows, since there are distinctive characteristics among product logistics and the reverse channels of distribution by which they flow, as well as the strategic objectives and operational techniques used in each area of action.

In the view of Chaves and Martins (2005), the managerial process of RL is responsible for making possible the return of materials and products after their sale and consumption to their business and production centers, by means of reverse distribution channels that aggregate value. Lacerda (2004) points out that the processes of RL have brought considerable returns to companies. The reuse of materials and the savings with returnable packaging have brought profits that stimulate more new initiatives and efforts for the development and improvement in the processes of RL. 
According to Fleury (2003), the RL flow has become commonplace for many companies, for example, manufacturers of tires, batteries, pesticides, beverages and aluminum. It is important to stress that not only companies participate in this reverse flow, but also the families and organizations that perform the collection, selection and compaction driven by the search for income and not only by legal mandate or concern with corporate image.

The channels of reverse distribution can be divided into two groups (LEITE, 2003): Postconsumer, which are constituted by the division of products and materials to be discarded from products after their original utility is finished and return to the production cycle, and Post-sale, composed by the different forms of return of products with little or no use, motivated by problems related to overall quality.

Tibben-Lemke (2002) and De Britto et al (2002), while commenting on the life cycle of the product and RL, relate the importance of considering - still in the development phase - the manner in which the discarding or reuse of pieces and parts will be conducted at the end of the life cycle.

\subsection{Selective collection}

The RL of post-consumption are characterized by utilizing practically the same structure and operation as the one used to deliver the product to the consumer, but going in the opposite direction, working with the materials discarded by society, which return to the business cycle or production cycle. Post-consumer goods are constituted by products at the end of their life cycle or used with possibility of re-utilization, and general industrial waste. There are three final destinations for the materials classified as post-consumer goods, when it comes to the life cycle: Secondary market; Recycling and Disassembly. For this study products at the end of their life cycle sent to recycling by the municipal service of selective collection was evaluated.

According to Leite (2003), secure final disposal is the discarding of goods in a controlled setting that does not damage, in any manner, the environment and does not affect, directly or indirectly, the society. Meanwhile, the non-secure disposal is the discarding of goods in an uncontrolled manner, in improper locations (vacant lots, streams, rivers, oceans, dumps, etc.), in improper quantities. El-Fadel et al (1997) point out that "Solid waste, if not properly discarded, can have disastrous effects on the environment, causing damage to water, air, soil and vegetation, also polluting with the formation of gases." According to Memon (2009), "Initially, the solid waste management (SWM) was aimed at reducing the risks to public health, and later the environmental aspect also became an important focus of SWM." Narayana (2009) notes that the problem of municipal waste has turned into a global challenge because of an exponentially increased population, rapid urbanization, worldwide industrialization, but also due to limited resources. 
Leite (2003) notes that the recycling system aggregates economic, ecological and logistic value to post-consumer goods, creating conditions to reintegrate the material to the production cycle, substituting for new raw materials, and generating a reverse economy; the reuse system adds reutilization value to post-consumer goods; and the incineration system adds economic value through the transformation of waste into electric power. The informal increase in value of waste represents at least one "adaptable" answer to the scarcity by which individuals collect recyclable material for personal use or sale (MEDINA, 2007). The same author highlights that the two most common motivations for the collection of waste discarded in urban dumps are the sale to industries and personal use.

The government has the responsibility to search for alternatives that will minimize the environmental impacts caused by discarding such waste materials. Among the alternatives, selective collection and the recycling of materials are the most adequate attitudes, considering the reuse of raw materials and energy and the generation of jobs and income (SILVA et al, 2003).

The reuse of materials can be a way to minimize the damaging effects to the environment, and logistics planning can bring effectively beneficial results to public or private organizations, once the process is well-structured in terms of localization of activities to establish the best route or means of transport. Additionally, its purpose continues to be the minimization of time spent, cost reduction and customer satisfaction. The adhesion of the population is necessary when it comes to the separation of waste that can be recycled. In general, industries already monetize leftover materials or packaging in the process of production or sale.

\section{Methodology}

This case study comprised 3 specific objectives: (1) to describe the process of collection, distribution, selection and compaction of solid waste. Thus, it will be possible to understand and evaluate how the chain of recyclable solid waste works; (2) to describe the profile of the workers involved and the risks to which they are exposed, in order to improve their work conditions; (3) to identify the management process of the associated and cooperative entities that act in this scenario. A more efficient and effective management may enhance the business performance

In order to understand the workers on the collection and selection of recyclables, a method of exploratory qualitative research was used by means of in-depth interviews using a semistructured script of questions. That method was applied primarily to the presidents of the Association and Cooperative of Collectors of Recyclables of Jaraguá do Sul, and afterward another semi-structured interview with one of the representatives of the company responsible for the selective collection and distribution of recyclable waste. In-depth semi-structured interviews were 
also developed with the Municipal Environmental Foundation and with the company that purchases the materials for replacement within the industry.

Non-participant observation was conducted to evaluate the working conditions of the associates and their work equipment. As Yin (2005, p. 24) points out, the case study constitutes an appropriate technique for the situations in which the researcher must answer the questions "how" and "why". The interviews lasted between 1 hour and 1hour and 30 minutes, were recorded and transcribed afterward. The transcriptions were organized in analytic categories according to the specific objectives, for better comprehension of the data.

\section{Analysis of results}

In the view of Manfredi, and Christensen (2009), The SWM becomes a complex and multidisciplinary problem, needed to be approached from technical, economic, social points of view in order to ensure it a sustainable basis, since the concept of environmental sustainability is a key criterion to design waste management systems.

The data collected allowed the description of how the process of collection, recycling and disposal of the city's solid waste takes place. The chain of recyclable domestic solid waste originated from the separation of domestic garbage is represented in figure 1: (I) Domestic Separation of garbage into organic and recyclable waste, (II) Selective Collection in parallel with common waste or not separated residues, (III) Screening and separation made at the association of collectors, at the cooperative of collectors and by families of independent collectors, (IV) Compression and Resale done by an industry in the region and (V) the industry that reprocesses all the material to transform it into new packaging and products.

Figure 1 - Chain of recyclable solid waste

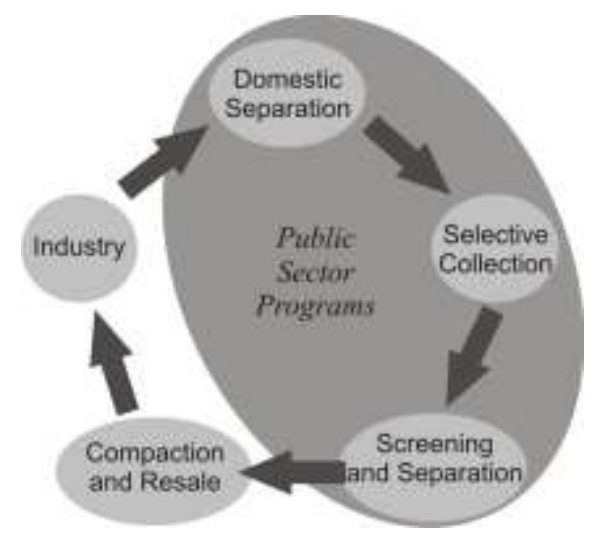

Parallel to the chain, as can be seen in Figure 1, it is observed that the municipal government develops actions to improve and expand the programs, reducing environmental liabilities and transforming the local culture. 
The next sections will describe the actors of the recyclable solid waste chain: the programs developed by the municipal government which support the domestic separation (I), the collection company hired by the Government organizes the selective collection (II), the association of collectors and the cooperative of collectors are responsible for screening and separation (III) and, finally, the company responsible for the purchase, compaction and reselling to the industry (IV).

\subsection{The association of collectors and the cooperative of collectors}

The interviews with the President of the Association and with the President of the Cooperative were conducted at the headquarters of the respective entities. They are legal entities, constituted in the form of Association for four years and Cooperative for 12 years. The entities divide among themselves the material of the selective collection organized by the government.

According to the interviewees, the material collected by the public selective collection program is delivered to the Association and the Cooperative. Daily amount of 6.8 metric tons of material from the city's 45,032 households are laid down at the entity headquarters. The work tools are improvised and the safety equipment for handling the material is inadequate. Only the use of boots and gloves as personal safety equipment was identified. Bags are attached to the table for the selection of several types of recyclables. The compaction process comes down to manually crushing aluminum cans, and also the breaking of glass packaging to facilitate transportation.

The materials handled and commercialized are primarily: paper, plastic, aluminum, glass and general metals. According to the president of the Association of Collectors, "Aluminum is more lucrative, but PET packaging has greater volume, and is responsible for the major part of the profit. Although it is material gathered by the selective collection, approximately $20 \%$ of the content is non-recyclable garbage".

There is one more common practice in the city: The retail commerce in the city center supplies its stores during the night, depositing the packaging, usually cardboard, on the sidewalks. This has generated a new form of collection by the Association, the Cooperative and independent collectors. The Association collects approximately 40 tons of cardboard a month with a team that only performs this work between midnight and 5 A.M. and does not take part in the separation and compression.

The Association has 13 members with most of the associates are between the ages of 30 and 40 years old. They have partially or totally completed primary education, and earn between US\$ 290.00 and US\$ 420.00 monthly. The first impression of the place is bad because of its harsh hygienic conditions. The plastic bags filled with domestic waste are emptied in mounds outdoors, where they await for screening and first compression. The greatest health risks faced by workers of the collection, selection and compression of recyclables, be it in the Association, Cooperative or 
independent collectors, are leptospirosis, tetanus, injuries caused by glass and respiratory illnesses related to cold and rain, as well as dehydration in the summer.

As far as business management is concerned, there is no formal planning for the actions of the cooperative: they are purely emergent and empirical. The decisions are taken as a group and executed by the president. The entire production of the Association, as well as the Cooperative and the independent collectors, is commercialized by a single company called Nicopel, which compresses into bales the previously separated material and resells it to industries. Collections are made daily and the payment is made upfront in cash. There is no formal control of the material received, only the material separated and sold to Nicopel company. There is no formal planning and the associates are involved and concerned exclusively with the execution of their work: separating recyclable waste.

\subsection{Collection company contracted by the government}

The interview with a member of the administrative team of the concessionaire company was conducted at the firm's headquarters. Empresa Ambiental (Environmental Company) has a contract with the Municipal Government to provide garbage collection services and selective collection of recyclables in all urban and rural areas of the municipality.

The collection is done with a van-type truck by two crews that work in two shifts. These crews are made up of two collectors and a driver. The selective collection crews take turns with the crews that collect common, non-selected garbage. In the last four years, the amount of recyclable waste selected in the households has averaged 70 tons per month.

The interviewee declared that "in December of 2010, 2,800 tons of garbage were collected in Jaraguá do Sul. Out of this amount, 150 tons are selected at the households. The companies that have leftover recyclable materials or packaging generally commercialize directly to the industry. The 150 tons of garbage from the selective collection are distributed for free and equally between the Association of Collectors and Cooperative of Collectors."

The company cannot estimate what quantity of recyclable material and what tonnage of common waste would be collected if all 45,032 households separated their garbage.

According to the company representative, they employ workers between the ages of 18 and 55 years old, and educational level between illiteracy and complete primary schooling. The salary is US\$ 490.00 complemented by additional hazard pay, bus passes and food vouchers. The main risks these workers face are basically the same as the associates who work at the selection of recyclable materials, with the aggravation of working amongst intense vehicle traffic. The president of the Association of Collectors was once a collection worker for Ambiental company. 


\subsection{Company responsible for the purchase, compaction and reselling}

The interview with the associate of the Nicopel company was conducted at the company headquarters. All of the municipality's independent recyclable garbage collectors sell their materials to Nicopel, along with the Association and the Cooperative of Garbage Collectors. According to the interviewee, 500 tons of this material is negotiated every month, in other words, 350 tons more than the amount collected by Ambiental company.

That means we go from 2,500 tons to 2,850 tons of waste. It can be affirmed that from the garbage collected from the city's households, only 17.5 percent of the total is effectively selected for recycling.

\subsection{Programs developed by the municipal government}

The interview with the manager of municipal programs focused on environmental education was conducted at the headquarters of FUJAMA - Jaraguá's Environmental Foundation (Fundação Jaraguaense do Meio Ambiente).

The municipal government acts through FUJAMA in the development and coordination of several projects, among them some related to post-consumer solid waste. According to the report, "Simply educating the people does not solve the problem. People are aware of the garbage and the environment, but so far very few of them conduct domestic separation.” According to Emery (2003) "In the residential sector, socio-economic status and housing characteristics affect not only the amount of municipal waste that individuals generate, but also how they manage it."

Chart 1 shows the steps in the chain of recyclable solid waste and the government's role in each step:

Chart 1 - Shows the steps in the chain of recyclable solid waste and the government's role in each step

\begin{tabular}{|c|c|c|c|}
\hline Step & Responsible Party & Function & Municipal Government Programs \\
\hline 1 & Citizen & Domestic separation & $\begin{array}{l}\text { Programs that encourage domestic garbage } \\
\text { selection through schools, neighborhoods, } \\
\text { companies and associations. }\end{array}$ \\
\hline 2 & $\begin{array}{l}\text { Ambiental } \\
\text { Company }\end{array}$ & $\begin{array}{l}\text { Conduct the selective collection } \\
\text { of recyclable solid waste in the } \\
\text { city's neighborhoods }(*) \text {. }\end{array}$ & $\begin{array}{l}\text { Bidding, contracting and payment of the } \\
\text { company responsible for collecting garbage and } \\
\text { cleaning the municipality's streets. }\end{array}$ \\
\hline 3 & $\begin{array}{l}\text { Association and } \\
\text { Cooperative of } \\
\text { Collectors }\end{array}$ & $\begin{array}{l}\text { Reception, separation, and first } \\
\text { compaction of the material by } \\
\text { category. }\end{array}$ & $\begin{array}{l}\text { Screening of the entities that will receive the } \\
\text { material, follow-up on the work and social } \\
\text { assistance to its members. }\end{array}$ \\
\hline 4 & Nicopel Company & $\begin{array}{l}\text { Purchase, final compaction and } \\
\text { resale of the separated material. }\end{array}$ & There is no government role at this step. \\
\hline 5 & Industry & $\begin{array}{l}\text { Purchase of compacted material } \\
\text { to be transformed into new } \\
\text { packaging. }\end{array}$ & There is no government role at this step. \\
\hline
\end{tabular}

Font: This research 
One of the educational projects is called Resíduo Tour (Waste Tour) and aims to cooperate with Jaraguá's community to reach environmental sustainability by means of ecologically correct actions, spreading good conservation and preservation practices, encouraging selective collection and adequate disposal of waste. The program has been developed in the municipality for 4 years, with activities one day per week. For the institution, "it is an awareness-raising work aimed at children, for these have a good capacity for assimilation of the subject in question, working as multipliers of knowledge, passing on the content to friends and family."

The objectives are (I) To know the work conducted in the selective collection's waste disposal and selection sites and follow the recycling steps until the final product, (II) to encourage improvement, disseminating the care that all must have when selecting the material to be sent to these sites, and (III) to make those involved in the selection work aware of the importance of their role to society. The children are taken to see the sites of disposal, waste selection and manufacturing of recyclable products. They also visit a company specializing in collection of construction waste and an industrial solid waste compaction and disposal company. In the year of 2010, about 2,200 children participated in this project.

Another program is Livro Livre (Free Book). It was created in the city of Blumenau, also in the state of Santa Catarina, and is directed by Instituto Evoluir. The objective of the Trade Trash for a Book project is to encourage environmental education and culture. Two findings are the basis for the program: (I) Children do not own books as a personal cultural asset, since the works usually belong to the school library, public library, or bookstore; (II) A great quantity of recyclable domestic waste is not properly disposed.

The program's operation is simple: The schoolchildren trade one kilogram of recyclable solid waste from their homes for one book. The garbage collected by them is commercialized and the money raised is kept by the school. According to the interviewee: "During the months of April and July of 2010, about 10 thousand children from the 32 municipal schools brought to them 74,723 kilograms of material. Through participation in the campaign, 55 thousand books were made available to students."

In a study of the recycling of domestic paper, Meneses and Palacio (2005) recommended that educational programs include components to build ecological awareness or environmental knowledge, ecological involvement and self-realization among citizens.

\subsection{Future actions}

Today, the monthly costs related to the processing of all the garbage of Jaraguá do Sul reach U\$ 350,000.00. To minimize these expenses, studies for the implantation of Treatment and 
Recycling Plants are underway. The costs to implement a plant are about U\$ 590,000.00. The cities in the region do not have a landfill and send their waste to another distant city $200 \mathrm{~km}$ away.

The implantation of a new, more efficient system will contribute to take better advantage of recyclable material. "The Supply Chain of the future will pressure governments and markets to reduce elimination costs and the amount of solid waste generated, altering the processes and materials used in manufacturing and transportation, reducing the environmental impact of packaging as well as altering the product itself, including design for reuse, remanufacturing and recycling" (BEAMON, 2008).

\section{Final considerations}

The analysis of this case study allows the inference that business management practices, the profile of the associates, the poor schooling and little provision of resources for reinvestment prevents the improvement of the conditions at the Association and the Cooperative, both in relation to the equipment and the development of business management skills. This does not prevent the implementation of some improvements, especially in relation to hygiene and cleanliness.

As for the process of selection and compaction, by part of the association, it is noticed that planning for the purchase of more adequate safety equipment is needed, as well as machines for grinding glass and plastic, and equipment for compacting metals, so that value can be added to the final product. A further need is the improvement of the warehouse structure. There is the interest, by part of the association, in training their members and in resource planning to improve their work.

The analysis allows the conclusion that the lack of training of the associates and their poor schooling can reflect the absence of planning, as well as the nonexistence of management of the scarce resources, which prevent their organization and development.

The work that has been developed by the local government takes up a great importance. It is the legal role of the government to effectively monitor the parties involved to avoid environmental harm and ensure the effective disposal of the material. It is also necessary to intensify the social programs in order to engage the population even more in the selection of domestic waste, as indicated by the rate of the material from selective collection in relation to the total of waste collected, according to our research findings. This is aligned with the theoretical reference by Leite (2003) about the final, secure disposal of solid waste and also by Silva et al (2003) in reference to the government's responsibility in the creating of alternatives to minimize the impacts.

When it is affirmed that "garbage belongs to all" there is the impression that, in effect, nobody is responsible. Above all, the garbage, even outside our residences, is ours. It is up to each person to separate recyclable garbage at home and up to the government to create programs to encourage this. 
The analysis of this case study indicates that there is a cycle that works and everyone has their role. However, the weakest link in this chain is the citizen, who knows what he must do and knows his importance in conserving the environment in which he lives. The problem is that, in the case study, a very small portion of the population actually separates domestic waste.

Some of the limitations of this study are generally, the difficulty in accessing the interviewees who perform the collection services, and the fact that a case study does not allow generalization, only the deeper understanding of a specific example. For future research studies, the gathering of information related to industrial solid waste and their rates of selection for recycling is suggested, due to the existence of many industrial plants in the city.

\section{Resumo}

Este artigo tem como objetivo descrever o processo de planejamento, coleta, distribuição, seleção e compactação de resíduos sólidos residenciais da cidade de Jaraguá do Sul no sul do Brasil. Foram levantadas informações na empresa responsável por realizar a coleta seletiva, na Associação e Cooperativa de Catadores e na empresa que vende o material, separado e compactado/triturado, para a indústria. Foi feito levantamento dos programas criados pelo poder público para sensibilização e conscientização da população quanto à importância da seleção do lixo doméstico. Dados qualitativos foram obtidos por meio de entrevistas semi-estruturadas e observação não participante. A análise dos resultados permitiu concluir que a falta de capacitação dos associados/cooperados e a baixa escolaridade podem explicar a ausência de planejamento. É possível também afirmar que o poder público municipal tem desenvolvido programas para a sensibilização da população, porém, ainda há resposta insignificante por parte dos habitantes daquele município.

Palavras-chave: Logística Reversa, Coleta Seletiva, Geração de Renda.

\section{References}

BEAMON, B. M., 2008. Sustainability and the Future of Supply Chain Management.

Operations and Supply Chain Management Vol. 1, No. 1, P 9

CHAVES, G.; MARTINS, R., 2005. Diagnosis of reverse logistics in the processed food supply chain in the West of Parana. In: Production Management, Logistics and International Operations, VIII, São Paulo, p.16 (in Portuguese)

DANIEL, C; GATES, R., 2005. Marketing Survey, São Paulo: Pioneira Thomson Learning. (in Portuguese).

El-FADEL, M., Findikakis, A.N., Leckie, J.O. 1997. Environmental impacts of solid waste landfilling. Journal of Environmental Management 50: 1-25.

cross ref

EMERY, A. D., GRIFFITHS, A. J., \& WILLIAMS, K. P. (2003). An in-depth study of the effects of socio-economic conditions on household waste recycling practices. Waste Manage Res, v.21 v.3, pp.180-90.

FLEURY, P., 2003. Logistics and Management of Supply Chian . São Paulo: Editora Atlas, p.475. (in Portuguese).

FORLIN, F. J.; FARIA, J. A. F., 2002. Remarks on recycling the plastics packings . Polymers: science and technology, v.12, n.1 p.1-10. (in Portuguese).

GIL, A. C., 2002. How to build research designs. 4. ed. São Paulo: Atlas. (in Portuguese). 
LEITE, P. R., 2003 Reverse logistics: environment and competitiveness. São Paulo: Pearson Prentice Hall. (in Portuguese).

LACERDA, L. Reverse Logistics - The vision over basic concepts and operational practices. In: http://www.coppead.ufrj.br/pesquisa/cel/new/fr-ver.htm. (in Portuguese).

MANFREDINI, S., and CHRISTENSEN, T.H. 2009. Environmental assessment of solid waste landfilling technologies by means of LCA-modelling. Waste Management, 29 (1), 32-43.

cross ref

MEDINA, M. 2007. The world's scavengers, salvaging for sustainable consumption and production. Lanham, MD: AltaMira Press.

MENESES, G.D., and PALACIO, A.B. 2005. Recycling Behavior: A Multidimensional Approach. Environment and Behavior, Vol. 37, No. 6, 837-860.

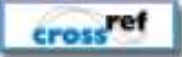

MEMON, M.A. 2010 Integrated solid waste management based on the 3R approach. J Mater Cycles Waste Manag V. 12 pp. 30-40.

cross ref

Narayana, T. 2009. Municipal solid waste management in India: From waste management disposal to recovery of resources? Waste Management, v.29, n.3, pp.1163-1166.

cross

SILVA, E. M. T.; DONEL F.; WOLLMANN A. R. e CUELLAR J., 2003. The planning as an implementation tool for selective collection urban solid wastes, ENEGEP, Ouro Preto, MG, October 21 to Decenber 24. (in Portuguese).

TIBBEN-LEMBKE, R. S., 2002. Life after death - reverse logistics and the product life cycle. International Journal of Physical Disribution \& Logistics Management, v. 32, n. 3, pp. 223-224.

\section{cross ref}

YIN, R. K., 2005. Case study research: Design and Methods, Applied Social Research Methods Series, Vol. 5, 3rd Edition. pp. 24

\section{Data from the Authors:}

Nome Completo: Ubiratã Tortato

Filiação institucional: Pontifícia Universidade Católica do Paraná

Departamento: Pós-graduação em Administração

Função: Professor

Endereço: Rua Imaculada Conceição, 1155 - Prado Velho

Curitiba - PR - CEP 80215-901

Telefone: (41) 3271-1476 - Fax: (41) 3271-1638

e-mail: ubirata.Tortato@pucpr.br

\section{Nome Completo: Marco Antonio Murara}

Filiação institucional: Pontifícia Universidade Católica do Paraná

Departamento: Pós-graduação em Administração 
Função: Acadêmico Mestrado

Endereço: Av. Mal. Deorodo da Fonseca, 776, sala 13

Centro - Jaraguá do Sul - SC

Telefone: 47 9125-9297 fax (47) 3371-7843

e-mail:marcoantonio@murara.com.br

Enviado em: 07/10/2011

Aprovado em: $14 / 08 / 2012$ 